\title{
Improving on estimates of the potential relative harm to health from using modern ENDS (vaping) compared to tobacco smoking
}

Nick Wilson ${ }^{1 *}$, Jennifer A. Summers ${ }^{1}$, Driss Ait Ouakrim², Janet Hoek ${ }^{1}$, Richard Edwards ${ }^{1}$ and Tony Blakely ${ }^{2}$

\begin{abstract}
Background: Although the harm to health from electronic nicotine delivery systems (ENDS) compared to smoked tobacco remains highly uncertain, society and governments still need to know the likely range of the relative harm to inform regulatory policies for ENDS and smoking.

Methods: We identified biomarkers with specificity of association with different disease groupings e.g., volatile organic compound (VOCs) for chronic obstructive pulmonary disease; and tobacco-specific N'-nitrosamines (TSNAs) and polycyclic aromatic hydrocarbons (PAHs) for all cancers. We conducted a review of recent studies (post January 2017) that compared these biomarkers between people exclusively using ENDS and those exclusively smoking tobacco. The percentage differences in these biomarkers, weighted by study size and adjusted for acrolein from other sources, were used as a proxy for the assumed percentage difference in disease harm between ENDS and smoking. These relative differences were applied to previously modelled estimates of smoking-related health loss (in health-adjusted life-years; HALYs).
\end{abstract}

Results: The respective relative biomarker levels (ENDS vs smoking) were: 28\% for respiratory diseases (five results, three studies); $42 \%$ for cancers (five results, four studies); and 35\% for cardiovascular (seven results, four studies). When integrated with the HALY impacts by disease, the overall harm to health from ENDS was estimated to be $33 \%$ that of smoking.

Conclusions: This analysis, suggests that the use of modern ENDS devices (vaping) could be a third as harmful to health as smoking in a high-income country setting. But this estimate is based on a limited number of biomarker studies and is best be considered a likely upper level of ENDS risk given potential biases in our method (i.e., the biomarkers used being correlated with more unaccounted for toxicants in smoking compared to with using ENDS).

Keywords: Electronic nicotine delivery systems, Vaping, Smoking, Biomarkers, Relative harm

* Correspondence: nick.wilson@otago.ac.nz

${ }^{1}$ University of Otago, Wellington, New Zealand

Full list of author information is available at the end of the article 


\section{Introduction}

The extent to which public health agencies and governments should restrict or support access to electronic nicotine delivery systems (ENDS), either as a means of quitting smoking or for harm reduction (relative to smoking) if long-term nicotine use persists, is controversial internationally. Previous estimates such as around $5 \%$ of the relative harm to health of ENDS use vs tobacco smoking [1, 2], are not disease-specific and have been critiqued, partly because they rely mainly on comparisons of emission levels from ENDS devices and tobacco smoking [3, 4], rather than studies of biomarkers or health outcomes. Studies of the relative harm of aerosol vs smoke are very limited because the relationships between emissions and biological outcomes remain unclear, and because ENDS users and smokers have different inhalation patterns. Other recent provisional review work on ENDS by a UK Government group makes only vague comments about ENDS having a "substantially lower" risk of adverse health effects compared to smoked cigarettes [5]. A recent review of six studies reported that former smokers who transitioned to e-cigarettes "showed 40\% lower odds of respiratory outcomes compared to current exclusive smokers" [6]. However, the authors also noted that "switching from smoking to e-cigarette [s] does not appear to significantly lower odds of cardiovascular outcomes." Overall, many limitations affect interpretation of these studies, as five were cross-sectional and only one was longitudinal.

Changes in ENDS technology also suggest the likely relative harm may change over time as device design and quality control of manufacturing processes of the e- liquid and nicotine salt solutions evolve. Dynamic product development and manufacturing suggest that estimates of relative harm should be based on data from recently conducted studies of ENDS.

Despite uncertainty about the health effects of ENDS use, societies and policy-makers still need to make policy on how they are regulated. Their decision-making often relies on modelling studies (e.g., as per these ones: [2, 717]), which require up-to-date and credible estimates of harm arising from ENDS use relative to tobacco smoking. The most recent of these modelling studies we identified, used a relative harm range from 5 to $20 \%$ [17], but did not provide a detailed justification for these values. Improved quantification of the relative harm should improve policy-making and assist smokers deciding whether it is better to switch to ENDS use or continue trying to quit all nicotine products.

In the absence of adequate long-term epidemiological data on the health effects of ENDS use, studies comparing levels of biomarkers associated with the occurrence of adverse health outcomes between exclusive smokers and ENDS users may provide more valid comparisons of relative health impacts than reviews using mainly emissions-based data. That is, biomarkers are likely to more closely represent the actual exposure of organs and tissues than will emissions-based studies. Select biomarkers for smoking-related toxicants are associated with key adverse health outcomes in smokers (Table 1), even though there is "variation in exposure due to differences in smoke composition across brands and to inherent variability among smokers" [18]. Therefore in this study we conducted a review of relevant and recent

Table 1 Relationship between health impacts from smoking and key biomarkers for toxicants

\begin{tabular}{|c|c|c|}
\hline $\begin{array}{l}\text { Health loss from } \\
\text { smoking }\end{array}$ & Biomarkers & Sources, comment \\
\hline $\begin{array}{l}\text { Chronic obstructive } \\
\text { pulmonary disease } \\
\text { (COPD) }\end{array}$ & $\begin{array}{l}\text { Volatile organic compounds (VOCs) } \\
\text { e.g., acrolein, crotonaldehyde }\end{array}$ & $\begin{array}{l}\text { The WHO [19], considers these agents to be hazardous with acrolein considered to } \\
\text { be: "an intense irritant, is toxic to lung cilia and has been proposed as a lung } \\
\text { carcinogen". Similarly, "crotonaldehyde is a potent irritant and a weak } \\
\text { hepatocarcinogen and forms DNA adducts in the human lung." }\end{array}$ \\
\hline All cancers & $\begin{array}{l}\text { Tobacco-specific } N^{\prime} \text {-nitrosamines } \\
\text { (TSNAs) } \\
\text { Polycyclic aromatic hydrocarbons } \\
\text { (PAHs) }\end{array}$ & $\begin{array}{l}\text { The WHO [19], notes that two TSNAs, "NNK and NNN, are probably responsible for } \\
\text { cancers of the lung, pancreas, oral cavity and oesophagus in tobacco users". "Both } \\
\text { have been classified as human carcinogens by working groups at [International } \\
\text { Agency for Research on Cancer] IARC." (See Table } 3 \text { regarding NNK and NNN and } \\
\text { the full terms). } \\
\text { The WHO [19], notes that: "many PAHs are potent carcinogens or toxicants in } \\
\text { laboratory animals (57), and many are present in cigarette smoke, including the } \\
\text { prototypic PAH benzo [a] pyrene, classified as a human carcinogen" by a working } \\
\text { group convened by the IARC. }\end{array}$ \\
\hline Cardiovascular disease & $\begin{array}{l}\text { Carbon monoxide }(\mathrm{CO}) \\
\text { Acrolein }\end{array}$ & $\begin{array}{l}\text { The WHO [19], states that: "CO is a well established cardiovascular toxicant, which } \\
\text { competes with oxygen for binding to haemoglobin. In smokers, it is considered to } \\
\text { reduce oxygen delivery, cause endothelial dysfunction and promote the } \\
\text { progression of atherosclerosis and other cardiovascular diseases". A US Surgeon } \\
\text { General's Report also states that: "the mechanisms by which CO may contribute to } \\
\text { acute cardiovascular events are well characterized" [20]. } \\
\text { The WHO [19] reports that: "cardiovascular tissues appear to be particularly } \\
\text { sensitive to the toxic effects of acrolein". A review on this association has also been } \\
\text { published [21]. }\end{array}$ \\
\hline
\end{tabular}


biomarker data with the aim of producing an updated estimate for relative harm of ENDS use compared to smoking.

\section{Methods}

To summarise, our method used the following three steps:

1. We identified biomarkers with specificity of association with different disease groupings: volatile organic compound (VOCs) for chronic obstructive pulmonary disease (COPD); tobacco-specific $\mathrm{N}^{\prime}$-nitrosamines (TSNAs) and polycyclic aromatic hydrocarbons (PAHs) for all cancers; and carbon monoxide and the $\mathrm{VOC}$, acrolein, for cardiovascular disease (CVD).

2. We conducted a review of recent studies (published and with data collected after January 2017) that compared these biomarkers (in blood, urine and exhaled breath) between people exclusively using ENDS and those exclusively smoking tobacco, determining the percentage difference in these biomarkers between ENDS users and smokers.

3. These percentage differences in biomarkers were assumed to reflect the percentage difference in disease harm, and were applied to previously modelled estimates of smoking-related health loss (in health-adjusted life-years; HALYs) to produce disease-group-specific and overall estimates of health loss for ENDS use versus tobacco smoking.

\section{Linking key biomarkers with categories of health loss}

For this process we relied on a recent key World Health Organization Report detailing recent biomarker research [19], supplemented with other key literature. The details are in Table 1.

\section{Literature searches to identify relevant biomarker studies of the differences in biomarkers between ENDS users and smokers}

Searches of the peer-reviewed literature were conducted using PubMed and Google Scholar on 1 September 2020 using the names of relevant toxicants and biomarkers as listed in a FDA Review document [22] (see Supplementary Information for further details and a PRISMA flow diagram: Supplementary Tables 1 to 3 ).

We considered studies published from 1 January 2017 to 1 September 2020. To be included, studies had to compare exclusive ENDS users to exclusive tobacco smokers for the relevant biomarker in either urine, blood or exhaled air. Studies based on data collected prior to 1 January 2017 were excluded as we aimed to focus on the most recent ENDS devices and to increase the probability that relatively modern quality control measures were being used by the manufacturers of devices and eliquids. Additional information describing the methodology of the review are provided in the Supplementary Information.

\section{Health loss by disease categories}

We used the results of a tobacco epidemiology and control modelling study [23], which has been extensively used for modelling tobacco control interventions [2429]. This model allows for the examination of tobacco control interventions on health across the whole life course in the population. It identifies HALYs gained from tobacco control interventions for preventing the following four disease groupings: COPD, cancers (a grouping of 12 tobacco-associated cancers), CVD, and lower respiratory tract infection [23]. The results for these different condition groups are detailed in Table 2.

\section{Integration of the relative biomarker results with the health impact results}

Our final analysis integrated the results of the relative biomarker levels (taking the weighted mean result with weighting based on study participant total numbers), and the relative HALY impacts from the epidemiological model (Table 2). But as one particular toxicant, acrolein, has other major sources (e.g., air pollution) we further adjusted the relative harm values for acrolein using data from the largest relevant study we found in the literature (Alwis et al. [30], see Supplementary Table 5). For this adjustment we assumed that other sources of acrolein (diet, air pollution etc) were non-differential between ENDS users and smokers.

For smokers who become ENDS users, the washout period used by the study may be important. That is for the biomarker NNAL, the half-life in the human body is 10 to 18 days [31]. Our analysis did include two crosssectional studies and one experimental study with 8 weeks of follow-up using NNAL. But given this half-life issue, we excluded results for NNAL from one shortterm experimental study lasting 5 days [32], where there would have been inadequate time for NNAL levels to have fully equilibrated with the transition to exclusive use of ENDS. But for all other biomarkers considered, half-lives were under $10 \mathrm{~h}$ and so this need for a long washout period was not relevant (see Table 3 footnotes).

\section{Results}

\section{Identified biomarker studies}

The results of our literature search and study selection process are shown in a PRISMA flow diagram (see Supplementary Information). Out of the 584 identified studies, five met our inclusion criteria by having appropriate comparison groups and data on contemporary ENDS devices (since 1 January 2017): Oliveri et al. 2020 [33], Jay 
Table 2 Health impacts by disease group as a result of modelling a tobacco control intervention (tobacco tax increases) at a national level [23]

\begin{tabular}{ll}
\hline Health condition / condition group & $\begin{array}{l}\text { Proportion of HALYs gained* from preventing uptake and promoting quitting of smoking } \\
\text { (undiscounted) }\end{array}$ \\
\hline $\begin{array}{l}\text { Chronic obstructive pulmonary disease } \\
\text { (COPD) }\end{array}$ & $48.9 \%$ \\
Cancers (12 types**) & $28.3 \%$ \\
CVD (coronary heart disease and stroke) & $22.4 \%$ \\
Lower respiratory tract infection & $0.4 \%$ \\
Total & $\mathbf{1 0 0 \%}$ \\
\hline
\end{tabular}

* Specifically from a tobacco tax intervention in New Zealand (a 10\% per annum increase in tobacco tax from 2011 to 2031 that impacts on both increasing quitting and reducing youth uptake), and values from Table S6 in the of Blakely et al. [23]. The HALYs are for the 2011 population over the remainder of their lifespans. Therefore, many of the health gains are decades into the future. American Cancer Society's Cancer Prevention Study II (CPS II) relative risks are used in this particular analysis (with results being similar to relative risks calculated from New Zealand studies)

* Cancers in descending order of importance as per the BODE ${ }^{3}$ preferred model: Lung cancer (26.0\%), bladder cancer (1.3\%), mouth and oropharyngeal cancer $(0.9 \%)$, oesophageal cancer $(0.9 \%)$, liver cancer $(0.9 \%)$, pancreatic cancer $(0.6 \%)$, stomach cancer $(0.6 \%)$, kidney cancer $(0.2 \%)$, cervical cancer $(0.2 \%)$, thyroid cancer $(0.0 \%)$, endometrial cancer $(-0.2 \%)$, melanoma $(-0.8 \%)$

et al. 2020 [32], Nga et al. 2020 [34], Boykan et al. 2019 [35], and Hatsukami et al. 2020 [36].

Two were experimental studies, one quasi-experimental and two were cross-sectional. In terms of study quality, two of the five studies were funded by commercial interests in ENDS use/tobacco [32, 33]. Nevertheless, a particular advantage of one of these was that it kept users in a controlled environment (albeit only for 5 days) [32], which may have reduced the risks of contamination via undeclared dual use of ENDS use and tobacco products, as well as exposure to secondhand smoke/ENDS aerosol from others. Other study design limitations of the included studies included involving narrow demographic groups (e.g., those aged 12 to 21 years [35]) and allowing participants to select products themselves [34], as opposed to being randomised. In the two cross-sectional studies, the authors had to rely on self-reporting as to participants being "exclusive" smokers or "exclusive" ENDS users. Further details on all these studies, including the specific ENDS products used are presented in Supplementary Table 4.

Many of the identified biomarker studies excluded from the analysis had collected data before our cut-off period of prior to January 2017 (e.g., [37-47]). Furthermore, some more recent studies did not involve appropriate comparison groups i.e., did not compare exclusive ENDS users with exclusive tobacco smokers (e.g., [48-52]). We excluded one study [53] because participants had occupational exposure to volatile chemicals (i.e., workers in a chemical factory). Another study on exhaled VOCs [54], was excluded because it was unclear whether the exhaled chemicals could be considered to be solely biomarkers or whether these also involved un-metabolised aerosol/ smoke from recent inhalation of the products.

\section{Biomarker results by disease categories}

Table 3 shows the results of the relative levels of the selected biomarkers. The mean results weighted by study size and adjusted for acrolein from other sources were: $28 \%$ for respiratory diseases (five results, three studies); $42 \%$ for cancers (five results, four studies); and 35\% for CVD (seven results, four studies).

\section{Integrated analysis of biomarkers and health loss}

When integrated with the HALY impacts from a modelled tobacco control intervention, by disease grouping, and with downward adjustments due to acrolein from other sources, the overall harm to health from ENDS was estimated at $33.2 \%$ that of smoking (Table 4 ).

\section{Discussion}

This analysis combined recent biomarker data from ENDS use (relative to smoking) with modelled smoking health loss data to produce an overall estimate of relative harm for ENDS use for four of the main disease groupings caused by smoking tobacco. Our method estimated that the harm associated with modern ENDS was $33 \%$ of the harm associated with tobacco smoking. This value is higher than previously suggested (e.g., at around 5\% [1, 2]) and the range of relative harm values (5 to 20\%) [17], used in the most recent modelling study we identified.

This 33\% estimate should be considered a likely upper level given potential biases in our method. A key such potential bias is that there may be more unmeasured toxicants correlated with the biomarkers we measured in smokers compared to ENDS users. Our reasoning is as follows. There are over 7000 chemicals in tobacco smoke, hundreds of which are toxic and around 70 which cause cancer [60]. In contrast, the best estimate we identified to date was of "over 80 " chemicals in ENDS aerosol [61]. Now assume the "representative" toxicant biomarker we used in our analysis for each disease did not capture all the causal mechanisms of tobacco smoking with disease (either 
Table 3 Results from the recent biomarker studies identified involving use of modern ENDS products (and data on exclusive ENDS use and exclusive smoking with data collection since 1 January 2017)

\begin{tabular}{|c|c|c|c|c|c|c|}
\hline Study & $\begin{array}{l}\text { Level in } \\
\text { exclusive } \\
\text { ENDS users } \\
{[A]} \\
\end{array}$ & $\begin{array}{l}\text { Level in } \\
\text { exclusive } \\
\text { smokers [B] }\end{array}$ & $\begin{array}{l}\% \text { of }[A] \\
\text { relative } \\
\text { to }[B]\end{array}$ & $\begin{array}{l}\text { ENDS } \\
\text { users } \\
\text { (N) }\end{array}$ & $\begin{array}{l}\text { Smokers } \\
\text { (N) }\end{array}$ & $\begin{array}{l}\text { Additional details* (with further details in the Supplementary } \\
\text { Information) }\end{array}$ \\
\hline \multicolumn{7}{|c|}{ Non-cancer chronic respiratory disease (VOCs) } \\
\hline $\begin{array}{l}\text { Jay et al. } \\
2020[32]\end{array}$ & 0.2 & 1.87 & $10.7 \%$ & 60 & 15 & $\begin{array}{l}\text { 3-HPMA; within group experiment**; mean level in mg over } 24 \mathrm{~h} \\
\text { (urine). }\end{array}$ \\
\hline $\begin{array}{l}\text { Hatsukami } \\
\text { et al. } 2020 \\
\text { [36] }\end{array}$ & 0.34 & 1.00 & $34.0 \%$ & 58 & 63 & $\begin{array}{l}\text { CEMA (biomarker for acrylonitrile) showing ratio relative to } \\
\text { exclusive smoking; RCT; within group relative change** }\end{array}$ \\
\hline $\begin{array}{l}\text { Hatsukami } \\
\text { et al. } 2020 \\
\text { [36] }\end{array}$ & 0.53 & 1.00 & $53.0 \%$ & 59 & 63 & $\begin{array}{l}\text { 3-HPMA showing ratio relative to exclusive smoking; } R C T \text {; within } \\
\text { group relative change** }\end{array}$ \\
\hline $\begin{array}{l}\text { Hatsukami } \\
\text { et al. } 2020 \\
\text { [36] }\end{array}$ & 0.53 & 1.00 & $53.0 \%$ & 58 & 63 & $\begin{array}{l}\text { HMPMA showing ratio relative to exclusive smoking; } R C T \text {; within } \\
\text { group relative change** }\end{array}$ \\
\hline $\begin{array}{l}\text { Oliveri } \\
\text { et al. } 2020\end{array}$ & 655.1 & 1232.4 & $53.2 \%$ & 59 & 54 & $\begin{array}{l}\text { 3-HPMA; cartridge-based product. Least squares mean level in } \mu \mathrm{g} / \\
\mathrm{g} \text { creatinine (urine). }\end{array}$ \\
\hline
\end{tabular}

[33]

\section{Weighted mean\#}

\section{All cancers (TSNAs and PAHs)}

$\begin{array}{lcc}\begin{array}{l}\text { Oliveri } \\ \text { et al. } 2020\end{array} & 28.6 & 230.1 \\ \text { [33] } & & \\ \begin{array}{l}\text { Boykan } \\ \text { et al. } 2019\end{array} & 10 & 56 \\ \text { [35] } & & \\ \text { Jay et al. } & 6.1 & 15.8 \\ 2020 \text { [32] } & & \\ \text { Hatsukami } & 0.47 & 1.00 \\ \text { et al. 2020 } & & \\ \text { [36] } & & \\ \text { Hatsukami } & 0.79 & 1.00 \\ \text { et al. 2020 } & & \\ \text { [36] } & & \\ \text { Weighted mean\# }\end{array}$

Weighted mean\#

$40.5 \%$

$12.4 \%$

$17.9 \%$

$38.6 \%$

$47.0 \%$

$79.0 \%$

$41.8 \%$

Cardiovascular disease (CO and acrolein)

\begin{tabular}{|c|c|c|c|c|}
\hline $\begin{array}{l}\text { Jay et al. } \\
2020 \text { [32] }\end{array}$ & 0.2 & 1.87 & $10.7 \%$ & 60 \\
\hline $\begin{array}{l}\text { Jay et al. } \\
2020 \text { [32] }\end{array}$ & 1.9 & 7.0 & $27.1 \%$ & 60 \\
\hline $\begin{array}{l}\text { Nga et al. } \\
2020 \text { [34] }\end{array}$ & 6.40 & 16.47 & $38.9 \%$ & 15 \\
\hline $\begin{array}{l}\text { Hatsukami } \\
\text { et al. } 2020 \\
\text { [36] }\end{array}$ & 0.43 & 1.00 & $43.0 \%$ & 58 \\
\hline $\begin{array}{l}\text { Hatsukami } \\
\text { et al. } 2020 \\
\text { [36] }\end{array}$ & 0.53 & 1.00 & $53.0 \%$ & 59 \\
\hline $\begin{array}{l}\text { Oliveri } \\
\text { et al. } 2020 \\
\text { [33] }\end{array}$ & 655.1 & 1232.4 & $53.2 \%$ & 59 \\
\hline $\begin{array}{l}\text { Oliveri } \\
\text { et al. } 2020\end{array}$ & 2.2 & 4.1 & $53.7 \%$ & 61 \\
\hline
\end{tabular}

Total NNAL; ng/g creatinine (urine), least squares mean level; cartridge based product

Total NNAL (the proportion above threshold of $14.5 \mathrm{pg} / \mathrm{mL}, \%$ ); aged 12 to 21 years old; convenience sample of outpatients.

NNN; mean ng over $24 \mathrm{~h}$ (urine); within group experiment**; the authors noted some anomalous results for NNN that concerned them.

Total NNAL showing ratio relative to exclusive smoking; $\mathrm{RCT}$; within group relative change ${ }^{* *}$. There was little difference between the relative levels at 4 weeks $(0.44)$ and 8 weeks (0.47).

PheT (phenanthrene tetraol) a PAH showing ratio relative to exclusive smoking; $\mathrm{RCT}$; within group relative change** 
Table 3 Results from the recent biomarker studies identified involving use of modern ENDS products (and data on exclusive ENDS use and exclusive smoking with data collection since 1 January 2017) (Continued)

\begin{tabular}{lllllll}
\hline Study & $\begin{array}{l}\text { Level in } \\
\text { exclusive } \\
\text { ENDS users } \\
{[A]}\end{array}$ & $\begin{array}{l}\text { Level in } \\
\text { exclusive } \\
\text { smokers [B] }\end{array}$ & $\begin{array}{l}\% \text { of }[\mathrm{A}] \\
\text { relative } \\
\text { to }[\mathrm{B}]\end{array}$ & $\begin{array}{l}\text { ENDS } \\
\text { users } \\
\text { (N) }\end{array}$ & $\begin{array}{l}\text { Smokers } \\
\text { (N) }\end{array}$ & $\begin{array}{l}\text { Additional details* (with further details in the Supplementary } \\
\text { Information) }\end{array}$ \\
\hline Weighted mean\# & & $42.9 \%$ & &
\end{tabular}

\section{*Terms and acronyms:}

3-HPMA 3-hydroxypropylmercapturic acid, a metabolite of acrolein. Half-life: 5-9 h [55].

CEMA 2-cyanoethylmercapturic acid (biomarker for acrylonitrile). Half-life: $8 \mathrm{~h}$ [56]

CO carbon monoxide

$\mathrm{COH} b$ Carboxyhaemoglobin, carbon monoxide measured from a blood sample, \% saturation. Half-life: 5-9 h [55]

eCO Exhaled carbon monoxide

HMPMA: 3-hydroxy-1-methylpropylmercapturic acid (biomarker for crotonaldehyde/methylvinyl ketone). Half-life: 5-9 h [55]

NNN N-nitrosonornicotine. Half-life: 45 min [55]

PAH Polycyclic aromatic hydrocarbons

PheT (phenanthrene tetraol), a PAH. Half-life: $8 \mathrm{~h}$ [57]

$R C T$ Randomised controlled trial

Total NNAL (4-(methylnitrosamino)-1-(3-pyridyl)-1-butanol) and its glucuronides, NNAL-O-glucuronide, and NNAL-N-glucuronide (ng/g creatinine). Half-life:

2-6 h [58]

TSNAs Tobacco-specific N'-nitrosamines

VOCS Volatile organic compounds

**B "within group" we compared the results at the start of the study when participants were all smokers with the results for the same group of individuals when they had all become ENDS users. All other comparisons in this table were between separate groups of exclusive ENDS users and exclusive smokers

\# Mean for category, weighted by total number of study participants (ENDS users plus smokers)

directly or by correlation), and that the occurrence of other correlated toxicants and mechanisms from ENDS use is less than with smoking tobacco (as suggested by the numbers of chemicals above), our method will likely have overestimated the percentage of harm from ENDS use as compared to smoking. For example, let us assume that acrolein is causally responsible for $60 \%$ of excess COPD due to smoking but $80 \%$ of excess COPD due to ENDS use (while ignoring toxicants and mechanisms correlated to acrolein). Then our method assumes all of the COPD variation can be explained by acrolein $(100 \% / 60 \%=$ 1.67 times overestimated). If we then apply it to ENDS use, this would lead to a net 1.33-fold overestimate $(80 \%$ times 1.67$)$. The net bias will vary further due to toxicants correlated to acrolein in ENDS aerosol. Indeed, in the unlikely circumstance of there being many other correlated toxicants with ENDS use (or a few very potent correlated toxicants), our method may actually under-estimate the harm from ENDS - but we believe this to be very unlikely.

To further illustrate the potential relevance of toxicants we have not included in our analysis, there is a systematic review [62], which reported that: "Most metal/ metalloid levels found in biosamples of e-cigarette users were similar or higher than levels found in biosamples of conventional cigarette users, and even higher than those found in biosamples of cigar users." We also did not identify any biomarker data relating to formaldehyde, which is commonly detected in ENDS products [63]. Similarly, we did not include fine particulates from ENDS, which may play a role in CVD [64]. Flavourings also differ between ENDS products, and some may have unique lung damaging effects [65]. We also did not include studies of biomarkers of tissue/physiological impact (e.g., respiratory lung inflammation, platelet

Table 4 Integrated analysis of the relative harm from using modern ENDS devices relative to smoking tobacco in terms of health loss in HALYs by disease grouping

\begin{tabular}{llll}
\hline Disease grouping & $\begin{array}{l}\text { \% HALY loss } \\
\text { (Table 2) [A] }\end{array}$ & $\begin{array}{l}\text { Relative harm of ENDS use vs smoking (Table 3 plus } \\
\text { adjusted for acrolein from other sources) [B] }\end{array}$ & $\begin{array}{l}\text { Relative harm in terms of } \\
\text { HALY loss (i.e., [A] x [B]) }\end{array}$ \\
\hline $\begin{array}{l}\text { Chronic obstructive } \\
\text { pulmonary disease (COPD) }\end{array}$ & $48.9 \%$ & $27.6 \%^{*}$ & $13.5 \%$ \\
Cancers (12 types) & $28.3 \%$ & $41.8 \%$ & $11.8 \%$ \\
Cardiovascular disease & $22.4 \%$ & $34.7 \%^{*}$ & $7.8 \%$ \\
Lower respiratory tract & $0.4 \%$ & $27.6 \%^{*}$ (as per COPD**) & $0.1 \%$ \\
infection & & & $\mathbf{3 3 . 2} \%$ \\
Total & $\mathbf{1 0 0} \%$ & & \\
\hline
\end{tabular}

*Adjusted for the best estimate of acrolein from non-smoking sources (e.g., diet) at 20.1\% of the level in smokers [30] (see Supplementary Information) **The basis for using the COPD approach is that "acrolein has powerful immune-suppressive effects on innate and adaptive immune cells" [18]. Furthermore, in the pathogen interaction studies in mice, exposure to acrolein after infection markedly worsened pulmonary immune defences [59] 
aggregation etc) given the lack of validation relative to chronic disease outcomes and/or because of the lack of direct comparisons between smoking and ENDS use.

Other limitations of our work include the following:

- Another reason why we may have over-estimated the relative harm of ENDS is that some "exclusive" ENDS users may have been "ex-smokers", some of whom may have still been smoking. This would result in an underestimate of the true difference in exposure between the groups. This may have been less likely in the experimental studies as each included a measure expected to reduce the likelihood of this bias operating. These measures were use of incentives for compliance [36], confinement to maximise restriction to the allocated product type [32], and screening for evidence of continued smoking [34, 35]. Nevertheless, although there was variation in the findings between studies, the two cross-sectional studies [33, 35], did not report a systematically higher level of biomarkers than the experimental studies, as might be expected if contamination by unreported continued smoking among exclusive ENDS users were greater in these studies.

- The disease categories we analysed only covered four main groupings of tobacco-related disease, but omitted less major ones. For example, there is evidence that smoking causes diabetes and increases the risk of tuberculosis, various eye diseases and immune system disorders such as rheumatoid arthritis [18]. Furthermore, some toxicants in ENDS products (e.g., acrolein) have also been associated with increasing the risk of diabetes [19].

- Within the disease categories we did not differentially weight particular toxicants by their likely importance in disease causation e.g., TSNAs vs PAHs in the "all cancers" grouping. While some work on relative prioritisation has been done (e.g., in tobacco-industry funded research [66]), this work does not appear to be comprehensive enough to produce reliable rankings. Furthermore, we did not consider non-linear dose response relationships. For example, lower levels of smoking intensity and second-hand smoke exposure have disproportionately higher relative risks for CVD than would be expected if the dose-response relationship was linear [18]. These non-linear relationships could mean that we have partly under-estimated the relative harm from toxicants that ENDS users are exposed to and that are associated with cardiovascular disease.

- The biomarker studies represent points in time in the long-term trajectory of ENDS use by individuals and within populations, and include diverse brands and product types (of both ENDS products and comparative tobacco brands). Trajectories of ENDS use and smoking may diverge further in the future. For example, smoked tobacco products have changed little over many decades and we suspect that many smokers will continue smoking long term at approximately the same intensity. However, we are less certain for ENDS use. ENDS users may be more or less likely to continue ENDS use long term compared to smokers. There may also be future changes to ENDS technology and usage patterns that affect exposure levels among ENDS users (e.g., based on changes in relative nicotine levels, or potential delineation of smokefree and vapefree areas, or if public tolerance of ENDS increases relative to smoking, or if ENDS products evolve further).

- More specifically, two of the biomarker studies involved short-term use of ENDS (i.e., for only five days [32], or just a matter of hours [34]). Usage patterns among short-term users may have differed from those exhibited by more experienced ENDS users and this could have impacted on their biomarker measurements.

- Some of the included biomarker studies had limitations and potential biases in their assessment of specific biomarkers among ENDS users. For example, while our analysis adjusted for other sources of acrolein (e.g. dietary sources), we did not have the data to adjust other biomarkers by exposure to secondhand smoke (or secondhand exposure to aerosol from ENDS). Nevertheless, such exposures are likely to be relatively minor given evidence that NNAL levels in non-smokers are typically $1-5 \%$ those of smokers (due to exposure to second-hand smoke) [22]. Also, although one study included results for a PAH [36], which has other sources (e.g., cooking emissions, vehicle emissions, and industrial air pollution [67]), this study had the advantages of being a randomised trial, thus such exposures should have been non-differential. But this study was still suboptimal for our purposes in terms of not also measuring PAH in a control group (nonENDS using and non-smoking), but it did show that PAH levels declined significantly in those switching to exclusive vaping.

- Two [32,33] of the five biomarker studies used in our main analysis were industry-funded. Given evidence that this conflict of interest is strongly associated with results favourable to the tobacco industry, indicating no harm of ENDS, further caution is required [68].

\section{Potential research implications}

The high level of uncertainty of the relative harm of ENDS use compared to smoking highlights the need to 
develop a much stronger evidence base. Agencies that fund research should therefore commission further studies that measure a wider range of biomarkers in longterm exclusive ENDS users and long-term exclusive smokers, in addition to long-term epidemiological studies that measure health outcomes. There is also a need for studies on the full range of ENDS products (and wide range of tobacco brands) and for regularly repeated studies given the rapid rate of technological development with ENDS to identify if new devices/e-liquids change biomarker levels. Also, given the limitations around the range of biomarkers in our analysis, additional biomarkers studied should include: PAHs, aromatic amines, acyclic amines, fine particulates, heavy metals and dysregulated metabolites [69]. There may also be a need for expert elicitation exercises involving toxicologists and epidemiologists to estimate the uncertainty ranges. In the interim, however, modelling work done to inform the regulation of ENDS and smoking, should probably use wide uncertainty intervals (as we have ourselves done [70]).

\section{Conclusions}

This analysis suggests that the use of modern ENDS devices (vaping) could be up to a third as harmful to health as smoking in a high-income country setting. This is best considered a likely upper level given the potential biases in our method (i.e., the biomarkers used being correlated with more unaccounted for toxicants in smoking compared to with using ENDS).

\begin{abstract}
Abbreviations
3-HPMA: 3-hydroxypropylmercapturic acid; CEMA: 2-cyanoethylmercapturic acid; CO: carbon monoxide; COHb: Carboxyhaemoglobin; COPD: Chronic obstructive pulmonary disease; CVD: Cardiovascular disease; eCO: Exhaled carbon monoxide; ENDS: Electronic nicotine delivery systems; HALY: Healthadjusted life-years; HMPMA: 3-hydroxy-1-methylpropylmercapturic acid; NNAL: (4-(methylnitrosamino)-1-(3-pyridyl)-1-butanol); NNN: Nnitrosonornicotine; PAH: Polycyclic aromatic hydrocarbons; PheT: Phenanthrene tetraol; RCT: Randomised controlled trial; TSNAs: Tobacco-specific N'-nitrosamines; VOCs: Volatile organic compounds; WHO: World Health Organization.
\end{abstract}

\section{Supplementary Information}

The online version contains supplementary material available at https://doi. org/10.1186/s12889-021-12103-x.

Additional file 1. Supplementary Information for: "Improving on estimates of the relative harm to health from using modern ENDS (vaping) compared to tobacco smoking".

\section{Acknowledgements}

We thanks Sophie Braznell from the University of Bath, United Kingdom, for helpful comments on the manuscript.

\section{Authors' contributions}

This work was designed by NW and TB. JH obtained the funding. Literature searches were conducted by JS, DAQ, and NW. Data analysis and writing the first draft was by NW. All authors assisted with revising manuscript drafts. All authors read and approved the final manuscript.

\section{Funding}

This work had funding support from the Cancer Society of New Zealand (Research Contract: Collaboration for Cancer Research Aotearoa New Zealand $(\mathrm{CCR}))$.

Availability of data and materials

All data generated or analysed during this study are included in this published article and its supplementary information file.

\section{Declarations}

Ethics approval and consent to participate

Not applicable.

\section{Consent for publication}

Not applicable.

\section{Competing interests}

The authors declare that they have no competing interests.

\section{Author details}

${ }^{1}$ University of Otago, Wellington, New Zealand. ${ }^{2}$ Population Interventions, Centre for Epidemiology and Biostatistics, Melbourne School of Population and Global Health, University of Melbourne, Melbourne, Australia.

Received: 15 January 2021 Accepted: 19 October 2021

Published online: 08 November 2021

References

1. McNeill A, Brose L, Calder R, Bauld L, Robson D. Evidence review of ecigarettes and heated tobacco products 2018. In: A report commissioned by Public Health England. London: Public Health England; 2018.

2. National Academies of Sciences Engineering and Medicine. Public health consequences of e-cigarettes. Washington, DC: The National Academies Press; 2018. https://doi.org/10.17226/24952.

3. Eissenberg T, Bhatnagar A, Chapman S, Jordt SE, Shihadeh A, Soule EK. Invalidity of an oft-cited estimate of the relative harms of electronic cigarettes. Am J Public Health. 2020;1 10(2):161-2. https://doi.org/10.2105/A JPH.2019.305424.

4. Burrowes $K$, Beckert $L$, Jones $S$. Human lungs are created to breathe clean air: the questionable quantification of vaping safety "95\% less harmful". N Z Med J. 2020;133(1517):100-6.

5. Committee on Toxicity of Chemicals in Food, Consumer Products and the Environment (COT). Statement on the potential toxicological risks from electronic nicotine (and non-nicotine) delivery systems ( $E(N)$ NDS - ecigarettes). Government of the United Kingdom, 2020. https://cot.food.gov. uk/sites/default/files/2020-09/COT\%20E\%28N\%29NDS\%20statement\%20202 0-04.pdf.

6. Goniewicz ML, Miller CR, Sutanto E, Li D. How effective are electronic cigarettes for reducing respiratory and cardiovascular risk in smokers? A systematic review. Harm Reduct J. 2020;17(1):91. https://doi.org/10.1186/s12 954-020-00440-w.

7. Kalkhoran S, Glantz SA. Modeling the health effects of expanding ecigarette sales in the United States and United Kingdom: a Monte Carlo analysis. JAMA Int Med. 2015;175(10):1671-80. https://doi.org/10.1001/jama internmed.2015.4209.

8. Hill A, Camacho OM. A system dynamics modelling approach to assess the impact of launching a new nicotine product on population health outcomes. Regul Toxicol Pharmaco. 2017;86:265-78. https://doi.org/10.1016/ j.yrtph.2017.03.012

9. Cherng ST, Tam J, Christine PJ, Meza R. Modeling the effects of E-cigarettes on smoking behavior: implications for future adult smoking prevalence. Epidemiol. 2016;27(6):819-26. https://doi.org/10.1097/EDE.00000000000004 97.

10. Levy DT, Borland R, Lindblom EN, Goniewicz ML, Meza R, Holford TR, et al. Potential deaths averted in USA by replacing cigarettes with e-cigarettes. Tob Control. 2017;27(1):18-25.

11. Levy DT, Borland R, Villanti AC, Niaura R, Yuan Z, Zhang Y, et al. The Application of a Decision-Theoretic Model to Estimate the Public Health Impact of Vaporized Nicotine Product Initiation in the United States. Nicotine Tob Res. 2016:19(2);149-159. 
12. Warner KE, Mendez D. E-cigarettes: comparing the possible risks of increasing smoking initiation with the potential benefits of increasing smoking cessation. Nicotine Tob Res. 2019;21(1):41-7. https://doi.org/10.1 093/ntr/nty062.

13. Soneji SS, Sung H-Y, Primack BA, Pierce JP, Sargent JD. Quantifying population-level health benefits and harms of e-cigarette use in the United States. PLoS One. 2018;13(3):e0193328. https://doi.org/10.1371/journal.pone. 0193328.

14. Petrović-van der Deen FS, Wilson N, Crothers A, Cleghorn CL, Gartner C, Blakely T. Potential country-level health and cost impacts of legalizing domestic sale of vaporized nicotine products. Epidemiol. 2019;30:396-404.

15. Doan TT, Tan KW, Dickens BSL, Lean YA, Yang Q, Cook AR. Evaluating smoking control policies in the e-cigarette era: a modelling study. Tob Control. 2020;29(5):522-30. https://doi.org/10.1136/tobaccocontrol-2019-054 951.

16. Levy DT, Yuan Z, Li Y, Alberg AJ, Cummings KM. A modeling approach to gauging the effects of nicotine vaping product use on cessation from cigarettes: what do we know, what do we need to know. Addiction. 2019; 114(Suppl 1):86-96. https://doi.org/10.1111/add.14530.

17. Mendez D, Warner KE. A magic bullet? The potential impact of e-cigarettes on the toll of cigarette smoking. Nicotine Tob Res. 2021;23(4):654-61. https://doi.org/10.1093/ntr/ntaa160.

18. U.S. Department of Health and Human Services. The Health Consequences of Smoking - 50 Years of Progress: A Report of the Surgeon General. Atlanta: U.S. Department of Health and Human Services, Centers for Disease Control and Prevention, National Center for Chronic Disease Prevention and Health Promotion, Office on Smoking and Health; 2014

19. World Health Organization. WHO study group on tobacco product regulation. Report on the scientific basis of tobacco product regulation. In: Seventh report of a WHO study group. (WHO Technical Report Series, No. 1015). Geneva: World Health Organization; 2019.

20. US Department of Health and Human Services. Smoking Cessation. A Report of the Surgeon General. Atlanta, GA: U.S. Department of Health and Human Services, Centers for Disease Control and Prevention, National Center for Chronic Disease Prevention and Health Promotion, Office on Smoking and Health; 2020. https://www.hhs.gov/sites/default/files/2020cessation-sgr-full-report.pdf

21. Henning RJ, Johnson GT, Coyle JP, Harbison RD. Acrolein can cause cardiovascular disease: a review. Cardiovasc Toxicol. 2017;17(3):227-36. https://doi.org/10.1007/s12012-016-9396-5.

22. Chang CM, Edwards SH, Arab A, Del Valle-Pinero AY, Yang L, Hatsukami DK. Biomarkers of tobacco exposure: summary of an FDA-sponsored public workshop. Cancer Epidemiol Biomark Prev. 2017;26(3):291-302. https://doi. org/10.1158/1055-9965.EPI-16-0675.

23. Blakely T, Cobiac LJ, Cleghorn CL, Pearson AL, van der Deen FS, Kvizhinadze $G$, et al. Health, health inequality, and cost impacts of annual increases in tobacco tax: multistate life table modeling in New Zealand. PLoS Med. 2015; 12(7):e1001856. https://doi.org/10.1371/journal.pmed.1001856.

24. Pearson $\mathrm{AL}$, Cleghorn $\mathrm{CL}$, van der Deen FS, Cobiac L, Kvizhinadze G, Nghiem N, et al. Tobacco retail outlet restrictions: health and cost impacts from multistate life-table modelling in a national population. Tob Control. 2017;26(5):579-85. https://doi.org/10.1136/tobaccocontrol-2015-052846.

25. van der Deen FS, Wilson N, Cleghorn CL, Kvizhinadze G, Cobiac $\amalg$, Nghiem $\mathrm{N}$, et al. Impact of five tobacco endgame strategies on future smoking prevalence, population health and health system costs: two modelling studies to inform the tobacco endgame. Tob Control. 2018;27(3):278-86. https://doi.org/10.1136/tobaccocontrol-2016-053585.

26. Cleghorn CL, Blakely T, Kvizhinadze G, van der Deen FS, Nghiem N, Cobiac $\sqcup$, et al. Impact of increasing tobacco taxes on working-age adults: shortterm health gain, health equity and cost savings. Tob Control. 2018;27(e2): e167-70. https://doi.org/10.1136/tobaccocontrol-2017-053914.

27. Nghiem N, Cleghorn CL, Leung W, Nair N, van der Deen FS, Blakely T, et al. A national quitline service and its promotion in the mass media: modelling the health gain, health equity and cost-utility. Tob Control. 2018;27(4):43441. https://doi.org/10.1136/tobaccocontrol-2017-053660.

28. Nghiem N, Leung W, Cleghorn C, Blakely T, Wilson N. Mass media promotion of a smartphone smoking cessation app: modelled health and cost-saving impacts. BMC Public Health. 2019;19(1):283. https://doi.org/10.11 86/s12889-019-6605-8.

29. Petrović-van der Deen FS, Blakely T, Kvizhinadze G, Cleghorn CL, Cobiac LJ, Wilson N. Restricting tobacco sales to only pharmacies combined with cessation advice: a modelling study of the future smoking prevalence, health and cost impacts. Tob Control. 2019;28(6):643-50. https://doi.org/1 0.1136/tobaccocontrol-2018-054600.

30. Alwis KU. deCastro BR, morrow JC, Blount BC. Acrolein exposure in U.S. tobacco smokers and non-tobacco users: NHANES 2005-2006. Environ Health Perspect. 2015;123(12):1302-8. https://doi.org/10.1289/ehp.1409251.

31. Goniewicz ML, Havel CM, Peng MW, Jacob P 3rd, Dempsey D, Yu L, et al. Elimination kinetics of the tobacco-specific biomarker and lung carcinogen 4-(methylnitrosamino)-1-(3-pyridyl)-1-butanol. Cancer Epidemiol Biomark Prev. 2009;18(12):3421-5. https://doi.org/10.1158/1055-9965.EPI-09-0874.

32. Jay J, Pfaunmiller EL, Huang NJ, Cohen G, Graff DW. Five-day changes in biomarkers of exposure among adult smokers after completely switching from combustible cigarettes to a nicotine-salt pod system. Nicotine Tob Res. 2020;22(8):1285-93. https://doi.org/10.1093/ntr/ntz206.

33. Oliveri D, Liang Q, Sarkar M. Real-world evidence of differences in biomarkers of exposure to select harmful and potentially harmful constituents and biomarkers of potential harm between adult E-vapor users and adult cigarette smokers. Nicotine Tob Res. 2020;22(7):1114-22. https:// doi.org/10.1093/ntr/ntz185.

34. Nga JDL, Hakim SL, Bilal S. Comparison of end tidal carbon monoxide levels between conventional cigarette, electronic cigarette and heated tobacco product among Asiatic smokers. Subst Use Misuse. 2020;55(12):1943-8. https://doi.org/10.1080/10826084.2020.1781180.

35. Boykan R, Messina CR, Chateau G, Eliscu A, Tolentino J, Goniewicz ML. SelfReported Use of Tobacco, E-cigarettes, and Marijuana Versus Urinary Biomarkers. Pediatrics. 2019;143(5):e20183531.

36. Hatsukami DK, Meier E, Lindgren BR, Anderson A, Reisinger SA, Norton KJ, et al. A randomized clinical trial examining the effects of instructions for electronic cigarette use on smoking-related behaviors and biomarkers of exposure. Nicotine Tob Res. 2020;22(9):1524-32. https://doi.org/10.1093/ntr/ ntz233.

37. Hecht SS, Carmella SG, Kotandeniya D, Pillsbury ME, Chen M, Ransom BW, et al. Evaluation of toxicant and carcinogen metabolites in the urine of ecigarette users versus cigarette smokers. Nicotine Tob Res. 2015;17(6):704-9. https://doi.org/10.1093/ntr/ntu218.

38. McRobbie H, Phillips A, Goniewicz ML, Smith KM, Knight-West O, Przulj D, et al. Effects of switching to electronic cigarettes with and without concurrent smoking on exposure to nicotine, carbon monoxide, and Acrolein. Cancer Prev Res. 2015;8(9):873-8. https://doi.org/10.1158/1940-62 07.CAPR-15-0058.

39. Cravo AS, Bush J, Sharma G, Savioz R, Martin C, Craige S, et al. A randomised, parallel group study to evaluate the safety profile of an electronic vapour product over 12 weeks. Regul Toxicol Pharmacol. 2016; 81(Suppl 1):S1-S14. https://doi.org/10.1016/j.yrtph.2016.10.003.

40. D'Ruiz CD, Graff DW, Robinson E. Reductions in biomarkers of exposure, impacts on smoking urge and assessment of product use and tolerability in adult smokers following partial or complete substitution of cigarettes with electronic cigarettes. BMC Public Health. 2016;16(1):543. https://doi.org/10.11 86/s12889-016-3236-1.

41. Aherrera A, Olmedo P, Grau-Perez M, Tanda S, Goessler W, Jarmul S, et al. The association of e-cigarette use with exposure to nickel and chromium: a preliminary study of non-invasive biomarkers. Environ Res. 2017;159:313-20. https://doi.org/10.1016/j.envres.2017.08.014.

42. Pulvers K, Emami AS, Nollen NL, Romero DR, Strong DR, Benowitz NL, et al. Tobacco consumption and toxicant exposure of cigarette smokers using electronic cigarettes. Nicotine Tob Res. 2018;20(2):206-14. https://doi.org/1 $0.1093 /$ ntr/ntw333.

43. Goniewicz ML, Gawron M, Smith DM, Peng M, Jacob P 3rd, Benowitz NL. Exposure to nicotine and selected toxicants in cigarette smokers who switched to electronic cigarettes: a longitudinal within-subjects observational study. Nicotine Tob Res. 2017;19(2):160-7. https://doi.org/10.1 093/ntr/ntw160.

44. Shahab L, Goniewicz ML, Blount BC, Brown J, McNeill A, Alwis KU, et al. Nicotine, carcinogen, and toxin exposure in long-term e-cigarette and nicotine replacement therapy users: a cross-sectional study. Ann Intern Med. 2017;166(6):390-400. https://doi.org/10.7326/M16-1107.

45. Round EK, Chen P, Taylor AK, Schmidt E. Biomarkers of tobacco exposure decrease after smokers switch to an E-cigarette or nicotine gum. Nicotine Tob Res. 2019;21(9):1239-47. https://doi.org/10.1093/ntr/nty140.

46. Carroll DM, Wagener TL, Stephens LD, Brame LS, Thompson DM, Beebe LA. The relationship between nicotine metabolism and nicotine and carcinogen 
exposure among American Indian commercial cigarette smokers and electronic nicotine delivery system users. Addict Behav. 2019;92:58-63. https://doi.org/10.1016/j.addbeh.2018.10.038.

47. Xia B, Blount BC, Guillot T, Brosius C, Li Y, Van Bemmel DM, et al. TobaccoSpecific Nitrosamines (NNAL, NNN, NAT, and NAB) Exposures in the US Population Assessment of Tobacco and Health (PATH) Study Wave 1 (20132014). Nicotine Tob Res. 2020;23(3):-583. https://doi.org/10.1093/ntr/ntaa1 10.

48. Dawkins L, Cox S, Goniewicz M, McRobbie H, Kimber C, Doig M, et al. 'Realworld' compensatory behaviour with low nicotine concentration e-liquid: subjective effects and nicotine, acrolein and formaldehyde exposure. Addiction. 2018;113(10):1874-82. https://doi.org/10.1111/add.14271.

49. Rubinstein ML, Delucchi K, Benowitz NL, Ramo DE. Adolescent Exposure to Toxic Volatile Organic Chemicals From E-Cigarettes. Pediatrics. 2018;141(4): e20173557.

50. Piper ME, Baker TB, Benowitz NL, Kobinsky KH, Jorenby DE. Dual users compared to smokers: demographics, dependence, and biomarkers. Nicotine Tob Res. 2019;21(9):1279-84. https://doi.org/10.1093/ntr/nty231.

51. Czoli CD, Fong GT, Goniewicz ML, Hammond D. Biomarkers of exposure among "dual users" of tobacco cigarettes and electronic cigarettes in Canada. Nicotine Tob Res. 2019;21(9):1259-66. https://doi.org/10.1093/ntr/ nty 174 .

52. Cobb CO, Lester RC, Rudy AK, Hoetger C, Scott M, Austin M, et al. Tobaccouse behavior and toxicant exposure among current dual users of electronic cigarettes and tobacco cigarettes. Exp Clin Psychopharmacol. 2020. https:// doi.org/10.1037/pha0000417.

53. Frigerio G, Mercadante R, Campo L, Polledri E, Boniardi L, Olgiati L, et al. Urinary biomonitoring of subjects with different smoking habits. Part I: profiling mercapturic acids. Toxicol Lett. 2020;327:48-57. https://doi.org/10.1 016/j.toxlet.2020.03.010

54. Papaefstathiou E, Bezantakos S, Stylianou M, Biskos G, Agapiou A. Comparison of particle size distributions and volatile organic compounds exhaled by e-cigarette and cigarette users. J Aerosol Sci. 2020;141:105487. https://doi.org/10.1016/j.jaerosci.2019.105487.

55. Gregg EO, Minet E, McEwan M. Urinary biomarkers of smokers' exposure to tobacco smoke constituents in tobacco products assessment: a fit for purpose approach. Biomarkers. 2013;18(6):467-86. https://doi.org/10.3109/13 54750X.2013.821523.

56. Jakubowski M, Linhart I, Pielas G, Kopecky J. 2-Cyanoethylmercapturic acid (CEMA) in the urine as a possible indicator of exposure to acrylonitrile. $\mathrm{Br} J$ Ind Med. 1987;44(12):834-40. https://doi.org/10.1136/oem.44.12.834.

57. Zhong Y, Wang J, Carmella SG, Hochalter JB, Rauch D, Oliver A, et al. Metabolism of [D10] phenanthrene to tetraols in smokers for potential lung cancer susceptibility assessment: comparison of oral and inhalation routes of administration. J Pharmacol Exp Ther. 2011;338(1):353-61. https://doi. org/10.1124/jpet.111.181719.

58. Underner M, Peiffer G. Interpretation of exhaled CO levels in studies on smoking. Rev Mal Respir. 2010;27(4):293-300. https://doi.org/10.1016/j.rmr.2 009.09.004.

59. Astry CL, Jakab GJ. The effects of acrolein exposure on pulmonary antibacterial defenses. Toxicol Appl Pharmacol. 1983;67(1):49-54. https://doi. org/10.1016/0041-008X(83)90243-0.

60. Centers for Disease Control and Prevention. Chemicals in Tobacco Smoke. (Reviewed 21 March 2011). https://www.cdc.gov/tobacco/data_statistics/ sgr/2010/consumer_booklet/chemicals_smoke/index.htm.

61. Thirion-Romero I, Perez-Padilla R, Zabert G, Barrientos-Gutierrez I. Respiratory impact of electronic cigarettes and "low-risk" tobacco. Rev Investig Clin. 2019;71(1):17-27. https://doi.org/10.24875/RIC.18002616.

62. Zhao D, Aravindakshan A, Hilpert M, Olmedo P, Rule AM, Navas-Acien A et al. Metal/metalloid levels in electronic cigarette liquids, aerosols, and human biosamples: a systematic review. Environ Health Perspect. 2020; 128(3):36001. https://doi.org/10.1289/EHP5686.

63. Dupont $\mathrm{P}$, Aubin HJ. Exposure of vapers to formaldehyde and acrolein: a systematic review. Rev Mal Respir. 2019;36(7):752-800. https://doi.org/10.101 6/j.rmr.2019.04.006

64. Kennedy CD, van Schalkwyk MCl, McKee M, Pisinger C. The cardiovascular effects of electronic cigarettes: a systematic review of experimental studies. Prev Med. 2019;127:105770. https://doi.org/10.1016/j.ypmed.2019.105770.

65. Holden VK, Hines SE. Update on flavoring-induced lung disease. Curr Opin Pulm Med. 2016;22(2):158-64. https://doi.org/10.1097/MCP.00000000000002 50
66. Cunningham FH, Fiebelkorn S, Johnson M, Meredith C. A novel application of the margin of exposure approach: segregation of tobacco smoke toxicants. Food Chem Toxicol. 2011;49(11):2921-33. https://doi.org/10.1016/j. fct.2011.07.019.

67. Vardoulakis S, Giagloglou E, Steinle S, Davis A, Sleeuwenhoek A, Galea KS, et al. Indoor Exposure to Selected Air Pollutants in the Home Environment: A Systematic Review. Int J Environ Res Public Health. 2020;17:8972-23.

68. Pisinger C, Godtfredsen N, Bender AM. A conflict of interest is strongly associated with tobacco industry-favourable results, indicating no harm of e-cigarettes. Prev Med. 2019;119:124-31. https://doi.org/10.1016/j.ypmed.201 8.12.011.

69. Wang Q, Ji X, Rahman I. Dysregulated Metabolites Serve as Novel Biomarkers for Metabolic Diseases Caused by E-Cigarette Vaping and Cigarette Smoking. Metabolites. 2021;11(6):345.

70. Summers J, Ait Ouakrim D, Wilson N, Blakely T. Updated health and cost impacts of electronic nicotine delivery systems, using recent estimates of relative harm for vaping compared to smoking. Nicotine Tob Res. 2021; ntab178. https://doi.org/10.1093/ntr/ntab178.

\section{Publisher's Note}

Springer Nature remains neutral with regard to jurisdictional claims in published maps and institutional affiliations.
Ready to submit your research? Choose BMC and benefit from:

- fast, convenient online submission

- thorough peer review by experienced researchers in your field

- rapid publication on acceptance

- support for research data, including large and complex data types

- gold Open Access which fosters wider collaboration and increased citations

- maximum visibility for your research: over $100 \mathrm{M}$ website views per year

At BMC, research is always in progress.

Learn more biomedcentral.com/submissions 